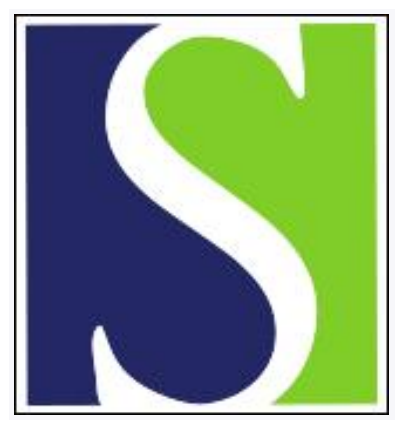

Scand J Work Environ Health 2009;35(3):163-179

https://doi.org/10.5271/sjweh.1319

Published online: 22 Apr 2009, Issue date: 00 May 2009

Shift work and the risk of ischemic heart disease - a systematic review of the epidemiologic evidence

by Frost $\mathrm{P}$, Kolstad $\mathrm{HA}$, Bonde JP

Affiliation: Danish Ramazzini Center, Department of Occupational Medicine, Århus University Hospital, Århus Sygehus, Noerrebrogade 44, Building 2C, 8000 Århus C, Denmark. poulfros@rm.dk

Refers to the following texts of the Journal: 2007;33(6):425-434 1999;25(2):85-99 1997;23(4):257-265 2005;31(1):30-35 2006;32(3):204-208 2008;34(3):206-212

The following articles refer to this text: 2009;35(3):157-161; 2010;36(2):96-108; 2010;36(2):150-162; 2010;36(2):81-84; 2010;36(6):515-516; 2011;37(4):263-275; 2012;38(6):590-599; 2014;40(3):287-294; 2015;41(3):288-293; 2015;41(3):268-279; 2015;41(4):347-355; 2017;43(2):117-126; 2018;44(3):225-228; 2020;46(5):508-515; 2022;48(7):511-519; 2022;48(7):520-529

Key terms: angina; cardiac function; epidemiologic evidence; IHD; ischemic heart disease; literature review; mortality; myocardial infarction; occupational health; review; risk; shift work; systematic review

This article in PubMed: www.ncbi.nlm.nih.gov/pubmed/19387517

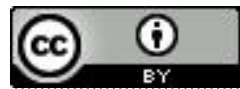




\title{
Shift work and the risk of ischemic heart disease - a systematic review of the epidemiologic evidence
}

\author{
by Poul Frost, MD, ${ }^{1}$ Henrik A Kolstad, MD, ${ }^{1}$ Jens Peter Bonde, MD ${ }^{1,2}$
}

\begin{abstract}
Frost P, Kolstad HA, Bonde JP. Shift work and the risk of ischemic heart disease - a systematic review of the epidemiologic evidence. Scand J Work Environ Health 2009;35(3):163-179.

Objective The objective of this review was to evaluate the epidemiologic evidence for a causal relation between shift work and ischemic heart disease.

Methods We conducted a systematic search until the end of March 2008 for studies providing information on the relative risk of ischemic heart disease in relation to shift work. The quality of included papers was evaluated with respect to design, exposure and outcome information, bias, and exposure response assessment.
\end{abstract}

Results Of the 16 studies examined, relevant information was retrieved from 14 . Seven of these analyzed fatal events, six combined fatal and non-fatal events, while one study reported separately on both types of events. Relative risks ranged from 0.6-1.4 in 12 papers while two papers reported relative risks around 2.0. Most studies based on fatal events showed no or weak associations while studies that combined fatal and non-fatal events showed modest positive associations. In a majority of studies, we could not reasonably rule out negative or positive bias due to the quality of outcome or exposure information, or confounder control. Five studies used years in shift work for exposure response analysis and no consistent pattern were seen.

Conclusion There is limited epidemiologic evidence for a causal relation between shift work and ischemic heart disease.

Key terms literature review; cardiac function; myocardial infarction; angina; mortality; occupational health.

Ischemic heart disease refers to a condition with disturbance of cardiac function due to a relative lack of oxygen in the myocardium. Most often this is caused by atherosclerosis in the coronary arteries. Reduction in myocardial perfusion can be limited by other causes such as thrombi, vascular spasms and other more rare conditions (1).

The 10th revision of the International Classification of Diseases (ICD) classifies ischemic heart disease into angina, myocardial infarction (or reinfarction) with or without complications, other acute ischemic heart diseases, and chronic ischemic heart disease.

Mortality by ischemic heart disease is declining in European countries but still an important cause of death. Based on the latest data, annually there are approximately 740000 deaths from ischemic heart diseases, 250000 of which occur among those aged 75 years or less (2). Information on morbidity data covering European Union (EU) countries is not available. In Nordic countries, national hospital discharge registers can be used to gather data about the incidence of hospitalization due to the subgroups of ischemic heart disease (3). In Denmark, for example, 24464 persons were hospitalized for the first time due to ischemic heart disease during 2002, of which 9736, 8919 and 5809 were due to angina, myocardial infarction, and other ischemic heart diseases respectively (4).

Socioeconomic status in both adulthood and childhood $(5,6)$, gender, lifestyle factors, including body mass index (7), and smoking, blood pressure, and blood cholesterol (7) are well-established risk factors for ischemic heart disease (8). It is likely that favorable population-wide changes, especially in smoking habits, but also in blood lipids and blood pressure, have contributed substantially to the decline in ischemic heart disease in European countries (9-11).

\footnotetext{
1 Danish Ramazzini Center, Department of Occupational Medicine, Århus University Hospital, Århus Sygehus, Århus, Denmark.

2 Department of Occupational Medicine, Copenhagen University Hospital Bispebjerg, Copenhagen, Denmark.
}

Reprint requests to: Dr P Frost, Danish Ramazzini Center, Department of Occupational Medicine, Århus University Hospital, Århus Sygehus, Noerrebrogade 44, Building 2C, 8000 Århus C, Denmark. [E-mail: poulfros@rm.dk] 
Shift work has been suggested as a risk factor for ischemic heart disease (12-15). In EU countries, about $20 \%$ of self-employed workers and employees work outside normal daytime hours (ie, 06.00-18.00). Shift work is most prevalent in agriculture, hotels, restaurants, transport, and healthcare $(16,17)$. A thorough presentation of possible causal mechanisms was given in a previous review (12). These included a mismatch of circadian rhythm, social disruption, and behavioral changes. A mismatch of circadian rhythm may have an influence on nutritional factors related to the timing of meals, lack of sleep, and stress related to sleep deprivation that could lead to unfavorable metabolic disturbances or a metabolic syndrome $(18,19)$. Working at night and sleeping during the day may disturb the social temporal pattern, and lead to social isolation and stress. An unfavorable distribution of behavioral factors such as smoking, poor diet, and over-consumption of alcohol could be influenced by shift work and thus be mediators of an effect of shift work on the risk of ischemic heart disease.

However, it is also possible that shift workers more often have an adverse health profile, since shift work is also related to lower socioeconomic status and lifestyle factors. The review by Bøggild \& Knutsson (10) found that in 6 out of 13 cross-sectional studies, shift workers were more likely to be smokers. In one study, shift workers were smokers less often, while in six studies no difference in smoking habits was found. The review found no strong indication that alcohol consumption or exercise differed.

The distributions of cardiovascular risk factors among shift workers and day workers were reported in six of the included studies (20-25), of which two used pre-employment information $(24,25)$. The prevalence of smoking was the same in one study and between $5-12 \%$ higher among shift workers in five studies. In one study, blood pressure and body mass index was related to shift work, while these factors were equally distributed in the remaining five studies. Socioeconomic status was measured in different ways in five studies, where lower status was consistently related to shift work $(20,21,23-25)$.

\section{Material and methods}

\section{Article selection}

We selected candidate articles for the reference document first on the basis of title and second on reading of the abstract. All candidate articles were retrieved prior to the final selection. The criteria for a study to be included in the review were: (i) original research written in English and published in a peer-reviewed journal, (ii) explicit information on shift work, (iii) estimates of the risk of ischemic heart disease, and (iv) use of a prospective design. In our selection, we did not require complete information on distributions of potential confounders or complete confounder control.

\section{Literature search}

The search aimed to identify relevant peer-reviewed epidemiological studies written in English providing information on the risk of ischemic heart disease in relation to night or shift work.

The review was based on an updated literature search in Medline (4 April 2008). The search terms were: "survival rate", "mortality", "odds ratio", "incidence" or "risk", and "cardiovascular diseases" or "coronary disease" or "cardiovascular" or "coronary near disease and "chronobiology disorders" or "circadian rhythm" or "work schedule tolerance" or "night near work" or "shift near work" or "shift work". The database search was supplemented by a bibliographic search in previous reviews in the field.

The three authors performed abstract reading to retrieve relevant articles, minimizing the possibility of selective selection.

\section{Article review}

The following elements were extracted from each of the selected articles and tabulated if present: (i) study design, (ii) sample size, (iii) follow-up time and completeness of participation, (iv) exposure assessment, exposure level, case definition and source of information, (v) confounder control (age, gender, blood pressure, blood cholesterol, smoking, physical activity, body mass index, family history of early onset coronary disease, and social class), and (vi) exposure response assessment. The strengths and limitations of each study were emphasized. This review described each study by year of publication, and presented results within studies grouped by comparable outcome assessment, (ie, mortality studies only using fatal cases and incidence studies combining fatal and non-fatal cases into a single outcome).

\section{Results}

The Medline search revealed 916 articles of which 54 abstracts were retrieved for reading. After reading the abstracts, we selected 14 full articles with relevance (20-33). We included two further articles $(34,35)$ identified from two previous reviews $(12,36)$. Thus, a total of 16 articles were included. Deaths by ischemic heart 
disease were analyzed in eight of the included studies (21, 24, 25, 27-29, 33, 35), of which all except one (27) were restricted to male populations. One study used hospitalized cases only (31), and fatal and non-fatal cases of heart or circulatory disease were combined into one outcome in six studies $(20,22,23,26,27,30)$. Three of these studies included female populations (23, $27,32)$. Two studies included cardiovascular disorders, other than ischemic heart disease, in their outcome definitions $(32,34)$.

The main characteristics of the retrieved studies can be found in table 1; they are ordered by publication year. A description of each study, in addition to its strengths and weaknesses, is provided in the following text.

\section{Description of the individual studies}

Taylor \& Pocock (29) performed a historical cohort study with 13 years of follow-up among 8603 fulltime male manual workers identified via pay rolls and employment records from ten factories in England or Wales. Inclusion criteria were: (i) at least ten years of continuous employment between 1946-1968, (ii) born before 1920, and (iii) alive in 1956. Information on working hours was obtained from company records. Day workers totaled 3860 while 4188 worked in threeshift rotas, alternate day and night, double days, rotating 12-hour shifts, or regular night work. Day workers, who during follow-up, transferred to shift work, were considered as shift workers if they completed six months of shift work.

A total of 1578 deaths were recorded, eight of which could not be traced in registers. The authors compared the observed number of deaths by ischemic heart disease (ICD-7: 420) obtained from death certificates among day and shift workers with the number of expected deaths, controlling for age and calendar time using mortality rates from England and Wales. Among shift workers, they observed 209 deaths by cardiovascular heart disease while 202.8 were expected. Cardiovascular heart disease resulted in the death of 200 day workers compared to the 211.9 expected. The results were reported as being statistically insignificant.

The strengths of this study included its relevant follow-up time, high participation rate, and independent information on shift work. A limitation of the study was its inadequate confounder control.

Angersbach et al (34) performed a historical cohort study with 11 years of follow-up among 640 male (370 shift and 270 day) workers in a chemical plant. Most shift workers worked alternating day and night shifts with a daily working time of 12 hours. Outcome was defined as hypertension, stenocardia, myocardial infarction, arrhythmias, etc., identified via health records in an occupational health centre or the firm's health insurance. During follow-up, $62(16.8 \%)$ shift workers and $40(14.8 \%)$ day workers fell ill.

The study had several limitations including its small study size, and inappropriate case criteria and case ascertainment.

Alfredson et al (26) performed a case-controlled study among males born between 1911-1935 in the catchment areas of two Swedish hospitals. They included 334 cases with fatal or non-fatal myocardial infarction (ICD 410.00 and 410.99) between 1974-1976 together with 882 age-matched controls. Based on a 1977 interview survey, participants were categorized as shift workers if they worked in occupations where at least $50 \%$ of working time was expected to alternate between day and night work. Individual information on occupational codes was obtained in 1970. The study did not provide any information on exposure distributions. In comparing shift working participants with those from other occupations, the authors found the age-standardized relative risk to be 1.25 [95\% confidence interval (95\% CI) 0.97-1.62].

The study's limitations included its small study size, indirect exposure information, and limited confounder control. In particular, a lack of control for socioeconomic status was a serious limitation in this population-based study.

Knutsson et al (22) performed a historical cohort study with 15 years of follow-up among 504 blue collar workers in the paper and pulp industry. In 1983, they collected information on shift work from the period 1968 to 1983 that was based on self report or from other sources if participants were deceased. Shift workers $(78 \%)$ worked three-shift rotas including day, evening, and night work. Ischemic heart disease was defined if participants, at follow-up, reported angina (pain or discomfort in the upper or midsternal region starting during effort and relieved by rest or nitroglycerine) or myocardial infarction. In most cases, self-reported data were checked against health records. The authors identified a total of 43 cases (25 myocardial infarction and 18 angina). It is unclear whether fatal cases were included.

Relative risk was analyzed in different ways, but the statistical methods used were not adequately reported. The authors noted a non-significant relative risk of 1.4. Relative risks according to years in shift work were: (i) 1.5 (2-5 years, not significant), (ii) 2.0 (6-10 years, not significant), (iii) 2.2 (11-15 years, $P=0.04$ ), (iv) 2.8 (16-20 years, $\mathrm{P}=0.03)$, and (v) 0.4 (21+ years, not significant). The authors reported a regression coefficient of 0.0774 with a P-value of 0.001. Controlling for smoking and family 
Table 1. Main characteristics of 16 epidemiological studies of shift work and risk of ischemic heart disease, 1972-2008. (NR = not reported, $\mathrm{BMI}=$ body mass index, ISCO = international standard classification of occupation, WHO = World Health Organization)

\begin{tabular}{|c|c|c|}
\hline $\begin{array}{l}\text { Study, year } \\
\text { and location }\end{array}$ & $\begin{array}{l}\text { Coronary } \\
\text { disease }\end{array}$ & $\begin{array}{l}\text { Design \& study population, } \\
\text { study period, \# of partici- } \\
\text { pants / cases / controls ( } \% \\
\text { included), \# of cohort cases }\end{array}$ \\
\hline $\begin{array}{l}\text { Taylor \& } \\
\text { Pocock, } \\
1972 \text { (29); } \\
\text { United } \\
\text { Kingdom }\end{array}$ & $\begin{array}{l}\text { Fatal cases } \\
\text { (ICD-7: 420) }\end{array}$ & $\begin{array}{l}\text { Cohort of full time male } \\
\text { manual workers, hired } \\
\text { between } 1946 \text { and } 1968 \text {, } \\
\text { born before } 1920 \text { and alive } \\
\text { in } 1956,1956-1968,8767 \\
(100 \%), 444\end{array}$ \\
\hline $\begin{array}{l}\text { Angersbach, } \\
1980(34) ; \\
\text { Germany }\end{array}$ & $\begin{array}{l}\text { Hypertension, } \\
\text { stenoncardia, } \\
\text { myocardial } \\
\text { infarction, } \\
\text { arrhytmias, } \\
\text { etc }\end{array}$ & $\begin{array}{l}\text { Cohort of workers in a } \\
\text { chemical plant, } \\
1966-1977,640 \\
(100 \%), 62\end{array}$ \\
\hline $\begin{array}{l}\text { Alfredson, } \\
1982(26) \\
\text { Sweden }\end{array}$ & $\begin{array}{l}\text { Fatal and } \\
\text { non-fatal } \\
\text { cases (ICD } \\
410.00 \text { and } \\
410.99)\end{array}$ & $\begin{array}{l}\text { Case-control study among } \\
\text { males born 1911-1935 in } \\
\text { the catchments areas of } \\
\text { Södertälje and Huddinge } \\
\text { hospitals, } 1974-1976,334 \\
\text { cases }(85 \%) \text { and } 882 \\
\text { controls }(91 \%)\end{array}$ \\
\hline $\begin{array}{l}\text { Knutsson } \\
\text { et al, } 1986 \\
(22) ; \\
\text { Sweden }\end{array}$ & $\begin{array}{l}\text { Fatal and } \\
\text { non-fatal } \\
\text { cases (angina } \\
\text { pectoris or } \\
\text { myocardial } \\
\text { infarction) }\end{array}$ & $\begin{array}{l}\text { Cohort of male blue-collar } \\
\text { workers at a paper and } \\
\text { pulp manufacturing plant, } \\
1968-1983,504(96 \%) \\
43\end{array}$ \\
\hline
\end{tabular}

\begin{tabular}{|c|c|c|}
\hline $\begin{array}{l}\text { Tüchsen, } \\
1993(31) \\
\text { Denmark }\end{array}$ & $\begin{array}{l}\text { Hospitalized } \\
\text { cases (ICD-8: } \\
410-414)\end{array}$ & $\begin{array}{l}\text { Cohort of employed males } \\
\text { aged } 20-59 \text { years on } 1 \\
\text { January } 1981,1981-1984 \text {, } \\
406969(100 \%), 5960\end{array}$ \\
\hline $\begin{array}{l}\text { Kawachi, } \\
1995(27) \text {; } \\
\text { United } \\
\text { States }\end{array}$ & $\begin{array}{l}\text { Non fatal and } \\
\text { fatal cases } \\
\text { (myocardial } \\
\text { infarction) }\end{array}$ & $\begin{array}{l}\text { Cohort of female nurses } \\
\text { from the Nurses' Health } \\
\text { Study Cohort, 1988-1992, } \\
79109(72 \%), 292\end{array}$ \\
\hline
\end{tabular}

\begin{tabular}{|c|c|c|c|c|}
\hline $\begin{array}{l}\text { Source of } \\
\text { exposure } \\
\text { information }\end{array}$ & $\begin{array}{l}\text { Exposure } \\
\text { criteria, } \\
\text { prevalence in } \\
\text { study base }\end{array}$ & $\begin{array}{l}\text { Source of } \\
\text { outcome } \\
\text { information }\end{array}$ & $\begin{array}{l}\text { Covariates } \\
\text { controlled for }\end{array}$ & $\begin{array}{l}\text { Exposure } \\
\text { response } \\
\text { assessment }\end{array}$ \\
\hline $\begin{array}{l}\text { Employment } \\
\text { records }\end{array}$ & $\begin{array}{l}10 \text { years of shift } \\
\text { work (3-shift } \\
\text { weekly or rapid } \\
\text { rotating, alternate } \\
\text { days and nights, } \\
\text { double days, } \\
\text { others): } 48 \%\end{array}$ & $\begin{array}{l}\text { Death } \\
\text { certificates }\end{array}$ & $\begin{array}{l}\text { Age, calendar } \\
\text { year }\end{array}$ & No \\
\hline NR & $\begin{array}{l}\text { Working in 2-shift } \\
\text { systems: NR }\end{array}$ & $\begin{array}{l}\text { Records from } \\
\text { occupational } \\
\text { health centres }\end{array}$ & None & No \\
\hline
\end{tabular}
Census data collected in 1970 or 1975
Occupations where Cause of at least $50 \%$ in a death register census reported and medical continuously day information and night work: system NR

Self-reported or from relatives, friends, or supervisors (if deceased) at end of follow up

\section{3-shift rotation: $78.2 \%$}

)

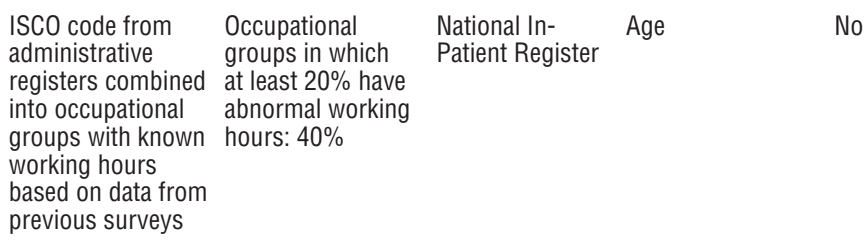

Primarily obtained Worked (mainly) Death from pay codes in a 3-shift system certificates and supplemented for a period of one by information month or more: from register of $\quad 59 \%$ dosimeters and medical notes in occupational health records tension, diabetes, records by phy- BMI, level of

NR Age, race, plant

No

Duration

(years) of

shift work:

$0,1-2,3-5$

6-9, 10-14,

$15+$

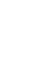

$\begin{array}{lll}\begin{array}{l}\text { certificates, } \\ \text { hospital and }\end{array} & \begin{array}{l}\text { Age, smoking, } \\ \text { and marital }\end{array} & \begin{array}{l}\text { Duration } \\ \text { (years) of } \\ \text { shift work: }\end{array} \\ \begin{array}{l}\text { occupational } \\ \text { health unit }\end{array} & \text { status } & 0,2-5, \\ \text { records } & & 6-10, \\ \text { assessed by } & & 11-15, \\ \text { cardiologist } & & 16-20, \\ \text { according to } & & 21+ \\ \text { WHO criteria } & & \\ & & \\ \text { National In- } & \text { Age } & \\ \text { Patient Register } & & \end{array}$


Table 1. Continued.

\begin{tabular}{|c|c|c|c|c|c|c|c|}
\hline $\begin{array}{l}\text { Study, year } \\
\text { and location }\end{array}$ & $\begin{array}{l}\text { Coronary } \\
\text { disease }\end{array}$ & $\begin{array}{l}\text { Design \& study population, } \\
\text { study period, \# of partici- } \\
\text { pants / cases / controls (\% } \\
\text { included), \# of cohort cases }\end{array}$ & $\begin{array}{l}\text { Source of } \\
\text { exposure } \\
\text { information }\end{array}$ & $\begin{array}{l}\text { Exposure criteria, } \\
\text { prevalence in study } \\
\text { base }\end{array}$ & $\begin{array}{l}\text { Source of } \\
\text { outcome } \\
\text { information }\end{array}$ & $\begin{array}{l}\text { Covariates } \\
\text { controlled for }\end{array}$ & $\begin{array}{l}\text { Exposure } \\
\text { response } \\
\text { assessment }\end{array}$ \\
\hline $\begin{array}{l}\text { Tenkanen } \\
\text { et al, } \\
1997(30) \text {; } \\
\text { Finland }\end{array}$ & $\begin{array}{l}\text { Fatal and } \\
\text { non-fatal } \\
\text { cases } \\
\text { (ICD-9: } \\
410-414)\end{array}$ & $\begin{array}{l}\text { Cohort study among male } \\
\text { blue-collar workers from } \\
\text { the Helsinki Heart Study, } \\
1987 / 88-1993,1806(65 \%) \text {, } \\
\text { NR }\end{array}$ & $\begin{array}{l}\text { Self reported by } \\
\text { questionnaire }\end{array}$ & $\begin{array}{l}\text { Worked } 2 \text { or } 3 \text {-shift, } \\
\text { irregular work and } \\
\text { night work: } 37 \%\end{array}$ & $\begin{array}{l}\text { Death and } \\
\text { hospital } \\
\text { discharge } \\
\text { register }\end{array}$ & $\begin{array}{l}\text { Age, smoking, } \\
\text { cholesterol, blood } \\
\text { pressure, BMl, } \\
\text { physical activity, } \\
\text { and alcohol } \\
\text { consumption }\end{array}$ & No \\
\hline $\begin{array}{l}\text { Bøggild } \\
\text { et al, } \\
1999(20) \text {, } \\
\text { Denmark }\end{array}$ & $\begin{array}{l}\text { Fatal and } \\
\text { non-fatal } \\
\text { cases } \\
\text { (ICD-8: } \\
410-414)\end{array}$ & $\begin{array}{l}\text { Cohort of male workers in } \\
\text { different industries between } \\
40-59 \text { years old from the } \\
\text { Copenhagen male study, } \\
1971-1993,5249(87 \%) \text {, } \\
1006\end{array}$ & $\begin{array}{l}\text { Self reported by } \\
\text { questionnaire } \\
\text { and interview }\end{array}$ & $\begin{array}{l}\text { Worked irregular } \\
\text { hours, shift work, } \\
\text { often night work: } \\
22 \%\end{array}$ & $\begin{array}{l}\text { National } \\
\text { Health Service } \\
\text { Register }\end{array}$ & $\begin{array}{l}\text { Age, tobacco, } \\
\text { weight, height, } \\
\text { social class, } \\
\text { fitness value, } \\
\text { sleep }\end{array}$ & No \\
\hline $\begin{array}{l}\text { Knutsson } \\
\text { et al, } \\
1999(23) \text {; } \\
\text { Sweden }\end{array}$ & $\begin{array}{l}\text { Fatal and } \\
\text { non-fatal } \\
\text { cases } \\
\text { (myocardial } \\
\text { infarction) }\end{array}$ & $\begin{array}{l}\text { Population based case- } \\
\text { referent study among } \\
\text { all } 40-70 \text { years old } \\
\text { citizens in Stockholm and } \\
\text { Vasternorrland counties, } \\
1992-1995,2006 \text { cases (NR) } \\
\text { and } 2642 \text { controls (NR) }\end{array}$ & $\begin{array}{l}\text { Self reported by } \\
\text { questionnaire }\end{array}$ & $\begin{array}{l}\text { During the most } \\
\text { recent } 5 \text { years } \\
\text { of work, worked } \\
\text { beyond day time } \\
(06.00-18.00): \\
10-12 \% \text { or } \\
\text { between } \\
22.00-06.00 \text { : } \\
2-3 \%\end{array}$ & $\begin{array}{l}\text { Hospital depart- } \\
\text { ments and dis- } \\
\text { charge, death } \\
\text { certificates, } \\
\text { and necro- } \\
\text { psy findings; } \\
\text { medical records } \\
\text { evaluated by } \\
\text { cardiologists }\end{array}$ & $\begin{array}{l}\text { Age, gen- } \\
\text { der, smok- } \\
\text { ing, job strain, } \\
\text { educational } \\
\text { level }\end{array}$ & No \\
\hline $\begin{array}{l}\text { Virtanen } \\
\text { et al, } \\
2001(33) \text {; } \\
\text { Finland }\end{array}$ & $\begin{array}{l}\text { Fatal cases } \\
\text { (ICD-9: 410) }\end{array}$ & $\begin{array}{l}\text { Cohort of employed males } \\
25-64 \text { years old in } 1980 \\
\text { from the Finnish Longitudinal } \\
\text { Census Data File, 1981- } \\
1994,507000 \text { (NR), } 8378\end{array}$ & $\begin{array}{l}\text { Job exposure } \\
\text { matrix (FINJEM) } \\
\text { developed by the } \\
\text { Finnish Institute } \\
\text { of Occupational } \\
\text { Health }\end{array}$ & $\begin{array}{l}\text { Worked evening } \\
\text { or 3-shift night: } \\
\text { NR }\end{array}$ & $\begin{array}{l}\text { National death } \\
\text { register }\end{array}$ & $\begin{array}{l}\text { Age, marital } \\
\text { status, follow-up } \\
\text { period, profes- } \\
\text { sional status, } \\
\text { income, educa- } \\
\text { tion and other } \\
\text { occupational } \\
\text { factors }\end{array}$ & No \\
\hline $\begin{array}{l}\text { Kalsson et } \\
\text { al, } 2005 \\
\text { (35); } \\
\text { Sweden }\end{array}$ & $\begin{array}{l}\text { Fatal cases } \\
\text { (ICD-9: } \\
410-414)\end{array}$ & $\begin{array}{l}\text { Cohort of male workers } \\
\text { in pulp and paper manu- } \\
\text { facturing, 1952-2001, } \\
5442(95 \%), 662\end{array}$ & Company files & $\begin{array}{l}\text { Job titles engaged } \\
\text { in shift work: } 42 \%\end{array}$ & $\begin{array}{l}\text { National Cause } \\
\text { of Death } \\
\text { Register }\end{array}$ & $\begin{array}{l}\text { Age, calendar } \\
\text { periods }\end{array}$ & $\begin{array}{l}\text { Duration } \\
\text { (years) of } \\
\text { shift work: } \\
\text { Never, <5, } \\
5-9,10-19 \\
20-29, \geq 30\end{array}$ \\
\hline $\begin{array}{l}\text { Fujino et al, } \\
2006(21) ; \\
\text { Japan }\end{array}$ & $\begin{array}{l}\text { Fatal cases } \\
\text { (ICD-10: } \\
\text { I20-I25) }\end{array}$ & $\begin{array}{l}\text { Cohort of employed } \\
\text { men from the Japanese } \\
\text { Collaborative Cohort Study } \\
\text { for the Evaluation of Cancer } \\
\text { Risk, } 1988-2003,17649 \\
\text { (NR), } 86\end{array}$ & $\begin{array}{l}\text { Self reported by } \\
\text { questionnaire }\end{array}$ & $\begin{array}{l}\text { In their working } \\
\text { life mainly worked } \\
\text { night: } 4.9 \% \text { or } \\
\text { mainly alternate } \\
\text { night and day } \\
\text { time: } 11.4 \%\end{array}$ & $\begin{array}{l}\text { Cause of death } \\
\text { retrieved } \\
\text { annually from } \\
\text { the Japan } \\
\text { Collaborative } \\
\text { Cohort } \\
\text { Study for the } \\
\text { Evaluation of } \\
\text { Cancer Risk }\end{array}$ & $\begin{array}{l}\text { Age, smoking, } \\
\text { alcohol intake, } \\
\text { hypertension/ } \\
\text { diabetes, edu- } \\
\text { cational level, } \\
\text { stress, hours of } \\
\text { walking, type } \\
\text { of job }\end{array}$ & No \\
\hline $\begin{array}{l}\text { Tüchsen } \\
\text { el al, } 2006 \\
\text { (32); } \\
\text { Denmark }\end{array}$ & $\begin{array}{l}\text { Hospitalized } \\
\text { cases } \\
\text { (ICD-8: } \\
\text { I390-I458 } \\
\text { and ICD-10: } \\
\text { I00-199) }\end{array}$ & $\begin{array}{l}\text { Cohort of males and females } \\
\text { from the Danish Working } \\
\text { Environment Cohort Survey, } \\
1991-2002,5517 \text { (95\%), } \\
562\end{array}$ & $\begin{array}{l}\text { Self reported } \\
\text { by interview at } \\
\text { baseline }\end{array}$ & $\begin{array}{l}\text { Not working on } \\
\text { permanent day } \\
\text { duty: } 17 \%\end{array}$ & $\begin{array}{l}\text { National Patient } \\
\text { Register }\end{array}$ & $\begin{array}{l}\text { Smoking, BMI, } \\
\text { passive smok- } \\
\text { ing, psychosocial } \\
\text { and ergonomic } \\
\text { work loads, noise, } \\
\text { monotonous work }\end{array}$ & No \\
\hline $\begin{array}{l}\text { Yadegarfar } \\
\text { \& McNamee, } \\
\text { 2008 (25); } \\
\text { United } \\
\text { Kingdom }\end{array}$ & $\begin{array}{l}\text { Fatal cases } \\
\text { (ICD: } \\
410-414)\end{array}$ & $\begin{array}{l}\text { Nested case-control study } \\
\text { among male industrial } \\
\text { workers at a nuclear fuel } \\
\text { company, aged <50 years } \\
\text { old, and hired between } \\
\text { January } 1950 \text { and end of } \\
1998,1950-1998,635 \text { cases } \\
(100 \%) \text { and } 635 \text { controls } \\
(100 \%)\end{array}$ & $\begin{array}{l}\text { Primarily } \\
\text { obtained from } \\
\text { pay codes and } \\
\text { supplemented } \\
\text { by information } \\
\text { from register of } \\
\text { dosimeters and } \\
\text { medical notes } \\
\text { in occupational } \\
\text { health records; } \\
\text { work status was } \\
\text { imputed for } 3.5 \%\end{array}$ & $\begin{array}{l}\text { Engaged in non-day } \\
\text { work for at least } 30 \\
\text { days: } 53 \%\end{array}$ & Death register & $\begin{array}{l}\text { Age, height, } \\
\text { weight, pre- } \\
\text { employment } \\
\text { blood pressure, } \\
\text { smoking and } \\
\text { social class }\end{array}$ & $\begin{array}{l}\text { Tests for } \\
\text { trend ac- } \\
\text { cording to } \\
\text { categories } \\
\text { of years of } \\
\text { shift work: } \\
0,1-4.9 \text {, } \\
5-9.9 \text {, } \\
\text { and } \geq 10 ; \\
\text { duration } \\
\text { analyzed } \\
\text { as a } \\
\text { continuous } \\
\text { variable }\end{array}$ \\
\hline
\end{tabular}


status did not alter risk estimates, and years in shift work remained significant after adjusting for age.

This study's limitations included retrospective selfreporting of shift work and its small study size. Although it was a strength that this study used an internal comparison group, residual confounding by age seems likely.

Tüchsen (31) performed a historical cohort study with four years of follow-up among Danish men aged 20-59 years in January 1981. The source population was identified in central registers. Occupational coding was obtained from another central register, which again was based on different administrative registers. The validity of this information is unknown. Data on working hours was obtained in 1976 from an interview survey with 5166 participants and from a survey among 1728 bakers in 1979. The data was allocated to all participants by occupational group. Sub-cohorts were constructed based on this information and relative risks were estimated. Historical information on occupational codes was not included. First time hospitalization due to ischemic heart disease (ICD-8: 410-414) during 1981-1984 was identified in the national in-patient register. The following standardized hospitalization ratios (SHR) were calculated by dividing the observed numbers by the expected number among 18 trades with mainly day work (eg, architects, lecturers, teachers, shop assistants, skilled, and unskilled workers) and multiplied by 100: (i) work predominately at night and early morning (eg, self-employed and skilled bakers), SHR $=193(90 \%$ CI 158.3-236.0); (ii) work in occupational groups in which at least $20 \%$ work late in the evening (eg, taxi operators, self-employed in hotels, cooks and waiters), SHR $=215$ (90\% CI 192.4-240.1); (iii) work covering 24 hour services (eg, fishermen, traffic staff, shipping and railway staff, bus and road transport staff, and rescue service/police, SHR=168 (90\% CI 151.8-185.5); (iv) work during irregular hours (eg, drivers and production workers, SHR $=172(90 \%$ CI 166.4-182.1). The study excluded certain occupational groups within healthcare due to a suspected problem with referral bias (37).

The limitations of the study included the unknown validity of occupational job coding, group-based and only prevalent exposure assessment, and inadequate confounder control, in particular of socioeconomic factors and smoking.

Kawachi et al (27) performed a prospective cohort study with four years of follow-up among 79109 women, all nurses aged 42 to 67 years who, in 1988, had answered a question on shift work. The source population was a 1976 cohort of 121700 female nurses aged 30-55 years who completed a baseline questionnaire in a nurses' health study. This cohort has been followed biannually with questionnaires to update information on risk factors and major illnesses. In 1988, 110141 eligible participants were asked about the total number of years during which they had worked rotating night shifts (at least three nights per month). The authors categorized responses into: "never", "1-2 years", "3-5 years", "6-9 years", "10-14 years" and " $15+$ years", and into "never" versus "ever". In total, $40.6 \%$ had never done shift work. The actual status in rotating night work was not requested. In 1988, those who were deceased, or previously had reported myocardial infarction, angina, or cerebrovascular disease were excluded. A comparison of non-responders and responders revealed that the former more often were current smokers, or had hypertension, diabetes, or hypercholesteroleamia. Among responders, the duration of shift work was associated with current smoking, body mass index, hypertension, diabetes, and higher levels of physical activity.

Cases of non-fatal myocardial infarction were identified by self report in 1992 and combined with information from medical records, if possible, or with an interview. Fatal cases were traced in death registers and the cause of death confirmed by medical or autopsy records, or death certificates when possible. A total of 292 cases, of which 44 were fatal, appeared.

The age-adjusted relative risk of fatal and non-fatal disorder was increased to 1.38 (95\% CI 1.08-1.76), and $1.31(95 \%$ CI 1.02-1.68) in multivariate analyses. The fully adjusted relative risk estimates tended to increase after six years of night work to 1.60 (95\% CI 1.05-2.42) but did not increase further with a longer duration of exposure. A test for a linear trend was reported to show a P-value of 0.04 when all the women were included, and a P-value of 0.2 when restricted to shift workers. The age-adjusted relative risk for fatal myocardial infarction was $1.23(95 \%$ CI $0.66-2.31)$ while the fully adjusted relative risk was 1.19 (95\% CI 0.63-2.23).

This study was strengthened by its use of a socioeconomic homogeneous cohort and the exclusion of already sick participants. Several relevant confounders were considered, but it was unclear how the authors controlled for smoking, which was quite strongly related to night shift work. Some important limitations included partial self reporting of outcome and self-reported retrospective exposure information with incomplete information on night work. The analyses of fatal outcome were based on only a few cases.

McNamee et al (24) performed a nested case-control study among male manual workers aged $\leq 50$ years and hired between January 1950 and December 1992. Information on shift work was based on company records characterizing each work day and complete for $72 \%$ of participants. A worker was considered exposed if he did shift work for at least one month; two thirds of employees worked in shift. The authors 
calculated the total number of years in shift work and performed a mean of 23 years of observations. They found that, on average, workers spent 10 years at the plant. No information on shift work was collected for employment periods prior to, or following, employment at the plant.

The United Kingdom Office of Population Censuses and Surveys notified the company of all deaths and their causes between 1950-1992. A total of 467 died from ischemic heart disease before the age of 76 years.

Information on height, blood pressure and weight was available from pre-employment medical examination records. Smoking status was known for only $53 \%$ of participants. The type of work was extracted from job titles. Controls were matched by year of hire and age.

Odds ratios were calculated with conditional logistic regression analysis and included other risk factors. The authors performed tests for trends after excluding day workers.

The adjusted odds ratio for shift work versus day work was 0.85 (90\% CI 0.65-1.12). No increasing trend in risk was observed when the duration of shift work was increased.

The strengths of this study included independent retrospective exposure information and thorough confounder control using pre-employment information on cardiovascular risk factors. The study was limited by its unclear definition of shift work and the fact that exposure information was not collected for periods worked outside the company. Moreover, the study lacked data on smoking for a large proportion of participants.

Steenland \& Fine (28) did a nested case-control study among a cohort of 21491 male workers at four plants. All cases were fatal resulting from ischemic heart disease while working or within one week of work ending. The study was published as a brief communication and contained no information on the follow-up period, calendar time, and source of outcome information or completeness. Adequate personal records of work type were available for 163 cases and five controls were selected matched on age, race, plant, and work status. The authors excluded controls with prior indication of heart disease. No information was available on smoking, obesity, socioeconomic status, or blood lipids. The type of fixed shift (day, afternoon, or night) at the time of death or match date was traced in personal records. A previous change of shift to the one held at the time of death or match date was also traced. Odds ratios were calculated by conditional logistic regression analyses and the results were as follows: (i) evening shift versus day shift workers 1.01 (95\% CI 0.66-1.52) and (ii) night shift workers versus day shift workers 0.64 (95\% CI 0.28-1.47).
Due to the limited information available on material and methods, the strengths and weaknesses of this study could not be fully assessed.

Tenkanen et al (30) performed a prospective cohort study with seven years of follow-up among 1806 males employed in five industrial companies. The study group was a sub-cohort within the Helsinki Heart Study, a placebo-controlled coronary prevention program among males, $40-55$ years old at entry. Industry participants were volunteers recruited and screened twice in 1982, with non high-density lipoprotein cholesterol $>=5.2 \mathrm{mmol} / \mathrm{l}$, and no evidence of current ischemic heart disease or any other illness. The authors included a sample of participants only screened once. The study allowed cases with previous diagnosis of cardiovascular disease. At the end of the coronary prevention study (1987-1988), 1806 of the 2794 eligible participants completed a psychosocial questionnaire and were followed up in registers until the end of 1993. Working hours were recorded on a 6-point scale. Working two or three shifts, irregular and night work were combined into one category as shift work and analyzed. Of the total cohort, $71 \%$ were blue collar workers and $37 \%$ performed shift work. Information on smoking, alcohol consumption, physical activity, body mass index, blood pressure, and serum lipids was collected in 1982. Psychosocial work loads were assessed by a questionnaire in 1986-1987, and occupational grouping (white or blue collar) was based on occupational codes. Ischemic heart disease (ICD-9: 410-414, number of cases not reported) was followed up in hospital and death registers. A previous hospitalization for heart disease was also noted.

The effects of shift work were assessed by a Cox proportional hazard analysis. Adjusted hazard ratios were (i) 1.38 (95\% CI 1.01-1.89) for all shift workers versus all day workers and (ii) 1.30 (95\% CI 0.91-1.97) for blue collar shift versus blue collar day workers. Analysis after the exclusion of previously diagnosed cardiovascular disease showed similar risk estimates to those on gemfibozil.

When compared with daytime academic and clerical workers, the increased relative risk for two-shift and three-shift workers was 1.9 (95\% CI $0.98-3.5)$ and 1.6 (95\% CI 0.94-2.7) respectively.

This study was limited by its relatively low participation rate and lack of analysis of drop outs, the inclusion of previously diseased persons in the cohort, and a low precision of risk estimates. A strength was its thorough confounder control.

Bøggild et al (20) performed a 22 year follow-up study among 5249 male workers, aged 40-59 years, recruited from different industries. The cohort was established in 1970-1971 as part of the Copenhagen male study 
with the purpose of studying cardiovascular risk factors. Information on shift work was obtained by a questionnaire and confirmed by an interview. Of the total, $22 \%$ did not work solely during daytime hours and consequently were classified as shift workers. No information on the duration of shift work was obtained. At the follow-up in 1985-1986, a change in shift work was assessed. Information on lifestyle factors, height and weight, blood pressure, fitness value, and social class was established at baseline. The study traced 1006 incidents of fatal or non-fatal ischemic heart disease (ICD-8: 410-414) in national registers on hospitalization and death.

Using the Cox proportional hazard method, the authors estimated an adjusted relative risk of 0.9 (95\% CI 0.7-1.1) among shift workers. There was no increase in risk among shift workers who changed to daytime working hours.

The strengths of this study included its high participation rate, a long and complete follow-up, thorough confounder control, and adequate statistical power. Considering the lack of expected associations, a major limitation was its crude exposure data that may have resulted in serious misclassification and lowered the chance of identifying cardiovascular effects related to shift work.

Knutsson et al (23) performed a population-based case control study including 2006 cases of fatal and nonfatal myocardial infarction and 2642 controls matched on gender, geographic region, and age. There was no information on participation rates. The study used data from two parallel programs on heart diseases. The source population comprised all citizens living in one of two regions in Sweden, aged 45-70 years, with no previous diagnosed heart disease at the start of the follow-ups in 1992 and 1993. Cases were traced for two to three years in death and hospital discharge registers, and at relevant hospital units in the regions. Shift work was assessed by questionnaire for the most recent five years of work. The study did not state how information concerning deceased cases was collected. If participants indicated they were working shifts or hours between $18.00-06.00$, they were categorized as shift workers. Participants who reported working hours between 22.00-06.00 were further categorized as night workers. All others were classified as day workers. Among male cases and controls, $18 \%$ and $12 \%$ reported shift work respectively. Among females, $16 \%$ of cases and $10 \%$ of referents reported shift work.

A questionnaire was also used to obtain information on smoking, job strain, and educational level. Risk among shift workers was analyzed for men and women by logistic regression. Among males, the relative risk was 1.3 (95\% CI 0.9-1.8) adjusted for job strain, educational level and smoking. Among females, relative risk was 1.6 (95\% CI 0.8-3.1).
The limitations of the study included its insufficient reporting of the participation rate, and an exposure assessment that covered only a short time period and different calendar periods. There was also limited confounder control, in particular there was a lack of adjustment for socioeconomic levels although this was a population-based study.

Virtanen et al (33) used data from the Finnish Longitudinal Census Data File containing national census since 1970. A closed cohort was established, restricted to $50 \%$ of employed males aged 25-64 years in 1980, and holding the same occupation in both 1975 and 1980. About 507000 participants were followed between 1980 and 1994. Working hours were classified into: (i) regular day, (ii) two-shift evening, or (iii) three-shift night categories based on the Finnish Job Exposure Matrix (FINJEM), allocating the exposure by occupational codes. Information on age, marital status, education, and income was taken from registers. Occupational class and category were coded into socioeconomic indicators.

A diagnosis of ischemic heart disease was traced in the national death register and 8378 cases were identified (ICD-9: 410). The relative risks related to work factors (including shift work) were only given if they were larger than 1.0, irrespective of statistical significance. Thus no result was presented since relative risk was less than unity.

The study's strengths included its independent measures of exposure and outcomes, large study size, and adequate adjustment for socioeconomic group. A limitation was its use of aggregated exposure assessment and a strong likelihood of considerable exposure misclassification.

Karlsson et al (35) performed a historical follow-up study among 2354 shift and 3088 day workers. The cohort included male workers employed in two pulp and paper plants for at least six months between January 1940 and the end of 1998, and aged <60 years at first employment. The authors assessed the duration of shift work using company records containing information on job title, employment periods, and workplace. Participants were categorized as either never having worked shifts (eg, electrical and mechanical maintenance workers, laboratory workers, and cleaners) or having done shift work (eg, workers in barking, grinding, screening, boiling, bleaching, and paper manufacturing) for the following periods: (i) $<5$ years, (ii) $5-9$ years, (iii) 10 19 years, (iv) 20-29 years, or (v) 30+ years. No censoring by age was used. The authors identified 662 deaths by ischemic heart disease between 1952-2001 in the national death register. They estimated relative risks adjusted for age and calendar year and found the overall 
relative risk to be 1.11 (95\% CI $0.95-1.30)$. The relative risks according to each exposure category were (i) shift work of < $<$ years: 0.85 (95\% CI $0.30-2.38)$; (ii) shift work of 5-9 years: 0.97 (95\% CI 0.56-1.67); (iii) shift work of 10-19 years: 0.83 (95\% CI 0.58-1.19); (iv) shift work of 20-29 years: 1.02 (95\% CI 0.77-1.36); and (v) shift work of $30+$ years: 1.24 (95\% CI 1.04-1.49).

A strength of this study was its use of independent exposure information. Its limitations were its inadequate confounder control and small sample size.

Fujino et al (21) used data from the Japanese Collaborative Cohort Study for the Evaluation of Cancer Risk (JACC study). The study included 17649 males in fulltime employment, aged 40-59 years between 1988-1990, and free of myocardial infarction or cerebrovascular diseases. A questionnaire was used to assess the extent of shift work at baseline. Of the total participants, $83.7 \%$ were categorized as day workers (mainly worked daytime hours), $11.4 \%$ as rotating shift workers (mainly worked alternate day and night time), and $4.9 \%$ as night workers (mainly worked night hours). A questionnaire was also used to obtain information about smoking, alcohol, hypertension, diabetes, educational level, perceived stress, hours of walking, exercise, and job type.

From data held by JACC study centres until the end of 2003, the authors traced 86 deaths by ischemic heart disease (ICD-10: I20-I25). Using the Cox proportional hazard method, adjusted relative risks were estimated for night workers to be 1.23 (95\% CI $0.49-3.10)$ and for shift workers 2.32 (95\% CI 1.37-3.95).

The study was limited by its low quality of exposure information and the few cases used.

Tüichsen et al (32) used data from the Danish Working Environment Cohort Survey. The study included 2853 male and 2664 female respondents, who were aged 20-59 years and gainfully employed in 1991. The study sample was drawn as a random sample from the general population. During the baseline interview, participants who reported that they worked two or three shifts (fluctuating, permanent evening, night, or early morning), or other non-day work were categorized as "exposed to working irregular hours". This represented $17 \%$ of respondents. Information about a number of work-related psychosocial, physical and chemical exposures, smoking, and body mass index was also obtained from the interviews.

The authors traced 562 cases of first hospital contact (ICD-8: I390-I458 or ICD-10: I00-I99) in registers from 1991 to 2002. Estimated by log linear regression, the adjusted relative risk was 1.31 (95\% CI 1.06-1.63) for irregular work hours.

This study was limited by its use of an inadequate outcome definition, qualitative exposure measures, and a lack of control of socioeconomic status.
Yadegarfar \& McNamee (25) performed a nested case control study in an industrial cohort different from the one reported previously (24). The cohort included all men aged $\leq 50$ years, who began working between January 1950 and December 1998 at a nuclear fuel company. The authors extracted information on daily working hours from company records using the same methods as in a previous study (24). A definition of shift work was used if workers had been engaged in non-day work for at least 30 days. The pattern of shift work schedules included three-shift systems and double day (mornings and afternoons) shifts. The authors also extracted the total number of years in shift work together with shift work status at end of employment.

Records from a pre-employment physical examination were used to obtain information on height, weight, blood pressure, and smoking. Social class was inferred from job codes.

Between 1950 and 1998, 635 deaths before the age of 75 due to ischemic heart disease (ICD: 410-414) were traced in death registers. An equal number of referents were drawn, matched on age, year of hire, and vital status. The authors performed a mean of 25.5 years of observations and found the average duration of employment at the factory to be 10.5 years for cases and 8.3 for referents. No information on shift work before or after hiring at the plant was collected.

Adjusted relative risk was estimated using conditional logistic regression. Additional analyses were performed to evaluate potential health-related selection into shift work.

The adjusted odds ratio for death by ischemic heart disease was 1.10 (90\% CI 0.91-1.32) compared with day workers without social class in the model. When social class was included, the adjusted odds ratio was 1.03 (90\% CI 0.83-1.28). Compared with day workers, an exposure response analysis revealed that odds ratios increased as the duration of shift work increased, but a test for trend was not significant.

This study had the same strengths and limitations as the study by McNamee el al (24).

\section{General findings}

\section{Overall risk}

We found a total of 16 studies on shift work and risk of ischemic heart disease published between 1972-2008. Point estimates of relative risks ranged between 0.64 and 1.15 in eight studies $(20,24,25,28,29,33-35)$ and between 1.25 and 1.35 in six $(22,23,26,27,30,32)$. The remaining two studies reported relative risk estimates around $2.0(21,31)$.

The case definitions varied. One study included hypertension and arrhythmia (34) while another (32) 
included all circular diseases in its outcome definition. Both, therefore, were not considered any further. Among the remaining 14 studies, 11 provided point estimates and $95 \% \mathrm{CI}$ of relative risk (figure 1).

The 14 relevant studies used outcome definitions that fell into two main categories: seven used mortality data (fatal cases) alone $(21,24,25,28,29,33,35)$ while six used incidence data by combining data on morbidity and mortality $(20,22,23,26,30,31)$. One study provided separate risk estimates for fatal cases versus non-fatal cases, and a combination of the two (27).

\section{Mortality studies}

Eight studies analyzed the risk of death by ischemic heart disease $(21,24,25,27-29,33,35)$. Table 2 gives an overview of the populations studies, the numbers of cases, exposure comparisons, point estimates of relative risk, and the confounders considered.

Two studies used employed males from the general populations $(21,33)$. Five studies included male workers from industrial settings, of which two were among two different groups of employees at the same facility (24, 25). Information on working hours was collected from company records in the five industry-based cohorts (24, $25,28,29,35)$ while two studies used self-reporting $(21$, 27 ) or an aggregated measure (33) to collect data. Two studies included participants over the age of 78 years $(29,35)$. The number of cases examined varied widely from 44 among 110141 nurses followed for four years (27) to 8378 cases among 507000 employed males followed for 13 years (33). In the remaining studies, the

Study

Alfredson et al 1982

Tuchsen 1993

Kawachi et al 1995

McNamee et al 1996

Tenkanen et al 1997

Bøggild et al 1999

Knutsson et al 1999

Karlsson et al 2005

Fujino et al 2006

Yadegarfar \& McNamee 2008

Steenland \& Fine 1996

Figure 1. Point estimates of relative risk of ischemic heart disease among night shift workers obtained from 11 epidemiologic studies. The size of the square symbol reflects the number of participants in the studies. number of cases ranged from 86 to 662 with follow-up periods from 15 to 49 years.

Participants were mainly allocated to shift work categories on the basis of not working during daytime hours. Most of these were engaged in rotating shifts including night work. The number of years spent in shift work was the only measure used in exposure response analyses $(24,25,35)$. One study analyzed risk in relation to evening and night work (33), and two studies looked at risk in relation to working mainly fixed at night $(21,28)$.

Three studies performed limited confounder control $(28,29,35)$ while the remaining studies controlled to some extent for socioeconomic factors, blood pressure, smoking, and body mass index. Two studies with 44 (27) and 86 (21) cases reported increased risk estimates of 1.19 and 2.35 respectively, while risk estimates ranged from 0.64 to 1.11 in six studies $(24,25,28,29$, 33, 35) with between 163 and 8767 cases. Two studies found no positive trend with years in shift work (24, 25), while one study reported a positive trend and a relative risk of 1.24 among those with at least 30 years of shift work (35).

\section{Incidence studies}

Seven studies used incidence data, combining mortality and morbidity data. Table 3 provides an overview of the results of these studies. Two studies provided information on the number of fatal and non-fatal cases $(22,27)$. Three studies $(23,26,27)$ used an outcome definition of fatal and non-fatal cases of myocardial infarction, while four studies $(22,30,31,20)$ used outcome definitions that in principle included angina, other acute or chronic ischemic heart diseases, as well as myocardial infarction. Four studies used occupational cohorts $(20,22,27,30)$ and three studies used general population sampling (23, $26,31)$. Information on working hours was based on self-report in five studies $(20,22,23,27,30)$, while an aggregated measure allocated on the basis of information on trade was used in two studies $(26,31)$. The number of cases varied from 43 (among 540 workers) followed for 43 years to 1006 (among 5249 workers) followed for 22 years. Participants were considered "exposed to shift work" if they were engaged in different shift systems, worked at night, had irregular working hours, or were employed in trades where the likelihood of working at night was considered high. In most of the studies, shift work was considered to include work between 24.00-06.00. Two studies performed exposure-response analyses $(22,27)$, while risk in relation to type of shift pattern was analyzed in one study (23). Three studies performed limited confounder control $(22,26,31)$, while four studies $(20,23,27,30)$ considered potential confounders more extensively. One study reported a risk 
Table 2. Mortality studies: night shift work and risk of ischemic heart disease. Findings from eight epidemiologic studies in male or female populations published between 1972 to 2008 . ( $\mathrm{Cl}=$ confidence interval. NR = not reported)

\begin{tabular}{|c|c|c|c|c|c|c|}
\hline $\begin{array}{l}\text { Study, } \\
\text { year, country }\end{array}$ & $\begin{array}{l}\text { Follow up period, } \\
\text { number, and setting }\end{array}$ & Outcome criteria & $\begin{array}{l}\text { Exposure } \\
\text { comparisons }\end{array}$ & $\begin{array}{l}\text { Measure } \\
\text { of risk }\end{array}$ & $\begin{array}{l}\text { Point estimate and P-value } \\
\text { or confidence intervals }\end{array}$ & $\begin{array}{l}\text { Confounders } \\
\text { considered }\end{array}$ \\
\hline \multicolumn{7}{|l|}{ Male populations } \\
\hline $\begin{array}{l}\text { Taylor \& Pocock, } \\
1972 \text { (29); United } \\
\text { Kingdom }\end{array}$ & $\begin{array}{l}1956-1968,8603 \\
\text { manual workers in } \\
\text { industry }\end{array}$ & $\begin{array}{l}\text { ICD-7: } 420 \\
\mathrm{~N}=444\end{array}$ & $\begin{array}{l}\text { Shift work versus } \\
\text { general population }\end{array}$ & $\begin{array}{l}\text { Standardized } \\
\text { mortality ratio }\end{array}$ & $1.03(P>0.05)$ & $\begin{array}{l}\text { Age and calendar } \\
\text { period }\end{array}$ \\
\hline $\begin{array}{l}\text { Steenland \& Fine, } \\
1996(28) ; \\
\text { United States }\end{array}$ & $\begin{array}{l}\text { NR, } 21491 \text { workers } \\
\text { in four heavy equip- } \\
\text { ment plants }\end{array}$ & $\begin{array}{l}\text { ICD-7: 410-414, } \\
N=163\end{array}$ & $\begin{array}{l}\text { Night work } \\
\text { versus day work }\end{array}$ & Odds ratio & $0.64(95 \%$ Cl 0.28-1.47) & Age, race, and plant \\
\hline $\begin{array}{l}\text { McNamee et al, } \\
1996(24) ; \\
\text { United Kingdom }\end{array}$ & $\begin{array}{l}\text { 1950-1992, NR, } \\
\text { industrial workers } \\
\text { in a nuclear fuel } \\
\text { production facility }\end{array}$ & $\begin{array}{l}\text { ICD-8: 410-414, } \\
N=467\end{array}$ & $\begin{array}{l}\text { Shift work versus } \\
\text { day work }\end{array}$ & Odds ratio & $0.85(90 \% \mathrm{Cl} 0.65-1.12)$ & $\begin{array}{l}\text { Age, pre- } \\
\text { employment blood } \\
\text { pressure, height, } \\
\text { weight, smoking, } \\
\text { and job status }\end{array}$ \\
\hline $\begin{array}{l}\text { Virtanen et al, } \\
2001(33) ; \\
\text { Finland }\end{array}$ & $\begin{array}{l}\text { 1981-1994, } \\
507000 \text { employed } \\
\text { males in general } \\
\text { population }\end{array}$ & ICD-9: $410, N=8378$ & $\begin{array}{l}\text { Two-shift evening } \\
\text { versus regular day; } \\
\text { three-shift night } \\
\text { versus regular day }\end{array}$ & Rate ratio & $\begin{array}{l}\text { The authors found } \\
\text { relative risk less then } \\
\text { unity; estimates NR }\end{array}$ & $\begin{array}{l}\text { Age, marital status, } \\
\text { socio-economic } \\
\text { indicators, and } \\
\text { calendar period }\end{array}$ \\
\hline $\begin{array}{l}\text { Karlsson et al, } \\
2005(35) ; \\
\text { Sweden }\end{array}$ & $\begin{array}{l}\text { 1952-2001, } \\
5442 \text { workers in } \\
\text { pulp and paper } \\
\text { manufacturing }\end{array}$ & $\begin{array}{l}\text { ICD-6: 4200-4203, } \\
\text { 4209; ICD-7: 4200- } \\
\text { 4202; ICD-8 and 9: } \\
\text { 411-414; ICD-10: } \\
\text { I20-I24, N= } 662\end{array}$ & $\begin{array}{l}\text { Shift work versus } \\
\text { day work }\end{array}$ & $\begin{array}{l}\text { Standardized } \\
\text { mortality ratio }\end{array}$ & $1.11(95 \%$ Cl 0.95-1.30 & $\begin{array}{l}\text { Age and calendar } \\
\text { period }\end{array}$ \\
\hline $\begin{array}{l}\text { Fujino et al, } \\
2006(21) ; \\
\text { Japan }\end{array}$ & $\begin{array}{l}\text { 1988-2003, } 17649 \\
\text { employed males }\end{array}$ & $\begin{array}{l}\text { ICD-10: } 120-125 \\
\mathrm{~N}=86\end{array}$ & $\begin{array}{l}\text { Mainly rotating } \\
\text { shifts versus mainly } \\
\text { day work; mainly } \\
\text { night work versus } \\
\text { mainly day work }\end{array}$ & Rate ratio & $\begin{array}{l}2.35 \text { (95\% Cl 1.37-3.95) } \\
1.23 \text { (95\% Cl 0.49-3.10) }\end{array}$ & $\begin{array}{l}\text { Age, smoking, } \\
\text { alcohol, hyper- } \\
\text { tension, diabetes, } \\
\text { stress, physical } \\
\text { activity, and job type }\end{array}$ \\
\hline $\begin{array}{l}\text { Yadegarfar \& } \\
\text { McNamee (25), } \\
\text { 2008; United } \\
\text { Kingdom }\end{array}$ & $\begin{array}{l}\text { 1950-1998, NR, } \\
\text { industrial workers } \\
\text { in a nuclear fuel } \\
\text { production facility }\end{array}$ & $\begin{array}{l}\text { ICD-NR: 410-414, } \\
\mathrm{N}=635\end{array}$ & $\begin{array}{l}\text { Non-day work } \\
\text { versus day work }\end{array}$ & Odds ratio & $1.03(90 \%$ Cl 0.83-1.28) & $\begin{array}{l}\text { Age, pre- } \\
\text { employment blood } \\
\text { pressure, height, } \\
\text { weight, smoking, } \\
\text { and social status }\end{array}$ \\
\hline \multicolumn{7}{|l|}{$\begin{array}{l}\text { Female } \\
\text { populations }\end{array}$} \\
\hline $\begin{array}{l}\text { Kawachi et al, } \\
1995(27) ; \\
\text { United States }\end{array}$ & $\begin{array}{l}1988-1992, \\
79109 \text { female } \\
\text { nurses }\end{array}$ & $\begin{array}{l}\text { Myocardial } \\
\text { infarction, } N=44\end{array}$ & $\begin{array}{l}\text { Rotating night work } \\
\text { with at least three } \\
\text { nights per month } \\
\text { versus less night } \\
\text { work or day work }\end{array}$ & Rate ratio & $1.19(95 \%$ Cl 0.63-2.23) & $\begin{array}{l}\text { Age, smoking, } \\
\text { hypertension, } \\
\text { diabetes, cholesterol, } \\
\text { body mass index, } \\
\text { contraceptives / } \\
\text { hormones, alcohol, } \\
\text { parental history, and } \\
\text { physical activity }\end{array}$ \\
\hline
\end{tabular}

estimate of 0.9 (20), five reported estimates between $1.25-1.40(22,23,26,27,30)$, while one study reported risk estimates of around 2.0 (31). In an analysis where workers with more than 20 years of shift work were excluded, one study reported a positive trend in risk (22). When comparing subjects who never work at night with those who do, one study reported a relative risk of 1.21 among workers with $<6$ years of rotating night shifts and 1.51 among those with $>6$ years (27).

\section{Gender effects}

Only two studies provided risk estimates among women exposed to shift work. Kawachi et al (27) reported relative risks of 1.19 for fatal cases, 1.34 for nonfatal cases and 1.31 for the combined case definition.
Knutsson et al (23) reported an odds ratio of 1.3, which was the same size as among males.

\section{Discussion}

Shift work, which often includes work at night, may be linked to ischemic heart disease. Possible causal mechanisms include unfavorable shifts in metabolic factors connected to disrupted circadian rhythm, increases in psychosocial stress, or unfavorable changes in smoking and eating habits. However, the evidence for these relationships is considered to be limited (12). This review included 16 studies. Of these, two provided limited contributions due to their inadequate outcome 
Table 3. Incidence studies: night shift work and risk of ischemic heart disease. Findings from seven epidemiologic studies in male or female populations using combined outcome measure published between 1980 and 2006 . ( $\mathrm{NR}=$ not reported, $95 \% \mathrm{Cl}=$ confidence interval)

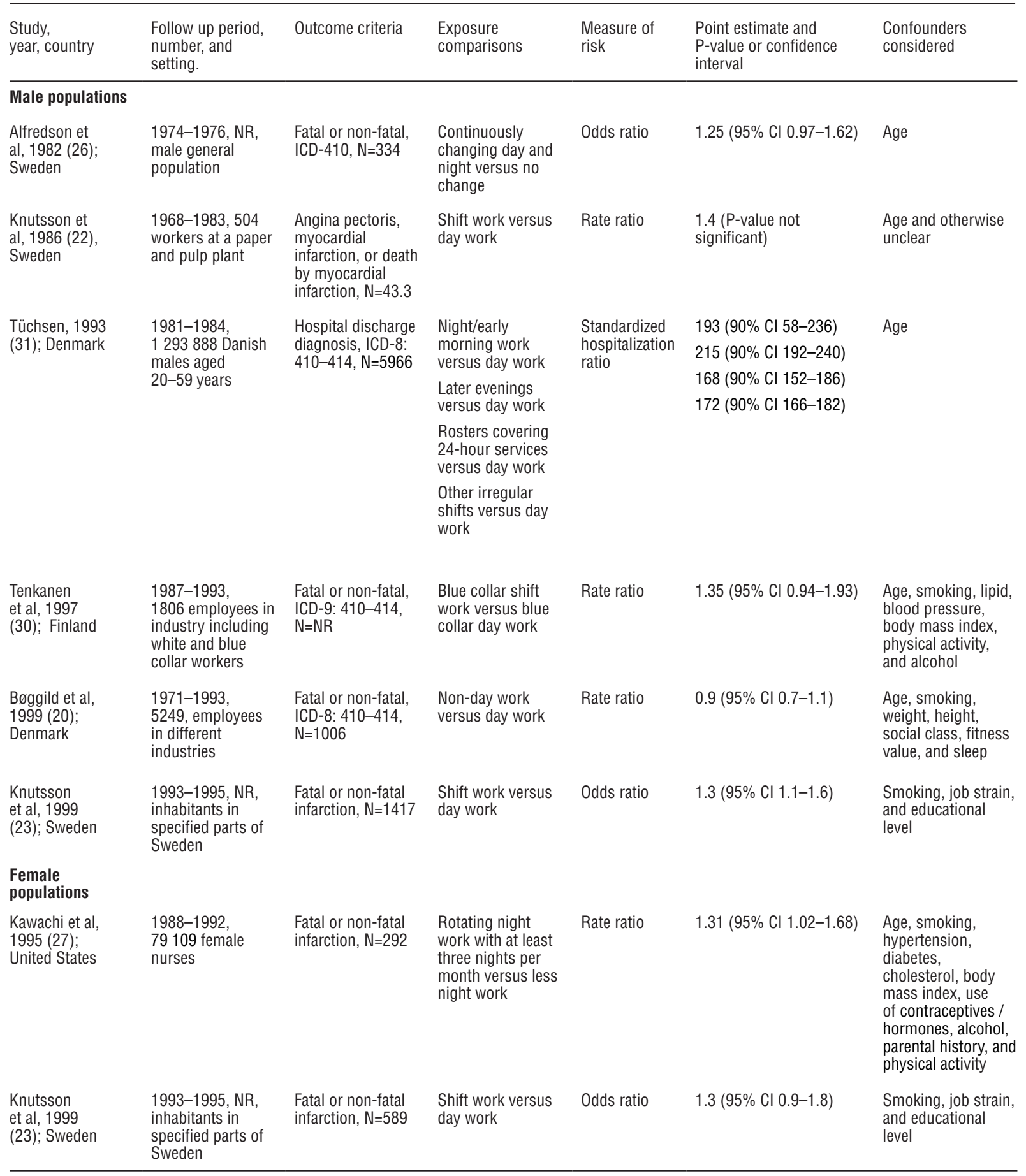


definitions $(31,34)$. In the remaining studies, relative risk estimates varied from 0.64 to 2.25 with most estimates around unity. Mortality studies generally showed lower risk estimates.

\section{Selection bias}

Participation rates and the completeness of follow-ups were high, above $80 \%$ in 11 studies and around $65-70 \%$ in two follow-up studies $(27,30)$, and not reported in one nested case control study (23). In one study (27), non-responders tended to experience more ischemic heart disease than responders (relative risk of 1.19, 95\% CI 0.96-1.48) and were more often current smokers $(29.7 \%$ versus $18.5 \%)$. In agreement with the authors of that study, we believe that a major bias due to selection would be unlikely, but that non-participation related to exposure could not be ruled out. One case control study did not report a participation rate but used a retrospective exposure assessment (23), making it vulnerable to exposure-related self-selection of cases.

Another issue of selection bias concerns the healthy worker mechanism, especially when comparing disease risk in working populations with the risk in general populations. One study (29) used such external comparisons and, as a result, may have underestimated risk in relation to shift work, since day workers had slightly reduced risk compared to the external reference group. Most other studies used cohorts free of disease in their follow-ups and, in general, health-related selection into shift work would be unlikely in the included studies. If having non-fatal ischemic heart disease could cause night workers to change to day shifts, the risk in relation to years in shift work could be underestimated, especially in studies of death by ischemic heart disease. This was not the case in a study using a cohort of Finnish nurses where the authors concluded that the possibility of employees with cardiovascular problems leaving their workplace was independent of work schedule (38). However, many subjects give up shift work within a few years - possibly due to adjustment difficulties - leaving behind the more robust and perhaps healthier workers. This could lead to an attenuation of exposure-response relations when using cumulative exposure measure. Two related studies $(24,25)$ addressed the issue of a "healthy shift worker survivor effect" attenuating exposure response relations, noting that the suggestions of such an effect could not be precluded, although the effect seemed small.

\section{Information bias}

In the studies examined, misclassification of outcome and/or exposure may have been systematically skewed. Studies have shown very different associations between certain psychosocial factors and subcategories of ischemic heart disease. This warrants careful consideration of the possibility of reporting bias. For this reason, separate analyses of sub-diagnoses of ischemic heart disease should be performed (39-41). It is less likely that a diagnostic coding of the cause of death would be systematically related to exposure status, but the accuracy of the death certificate diagnosis of ischemic heart disease is modest (42). Misclassification of outcome in studies based on mortality would thus tend to underestimate the true effect of shift work. In general, mortality studies showed lower risk estimates than incidence studies.

On the other hand, outcome measures that are based, or partly based, on self report or hospitalization, may inflate risk estimates due to a referral bias $(37,41,43)$. In Denmark, for example, almost half of those hospitalized for ischemic heart disease had a sub-diagnosis of angina (4). Three incidence studies only included myocardial infarction $(23,26,27)$. In these studies, relative risks were $1.3,1.25$, and 1.3 respectively. In four studies $(20,22$, $30,31)$, all sub-diagnoses of ischemic heart disease were included, with risk estimates of 0.9, 1.4, 1.4 and around 2.0 respectively. Separate analyses on sub-diagnoses of ischemic heart disease were not performed. Kawachi et al (27) showed lower risk estimates for fatal (as opposed to non-fatal) myocardial infarction, but the number of cases was low. As mentioned above, risk estimates concerning ischemic heart diseases in relation to psychosocial loads may be substantially biased due to differential reporting of symptoms. Angina possibly contributed a substantial proportion of cases in some studies $(20,22,30,31)$ but risk estimates in these were of comparable sizes to those that accepted only myocardial infarction as the outcome. This indicates that self-reporting of symptoms or self-referral to a hospital may not be strongly related to exposure status.

Considering the hypothesis of disturbed circadian rhythm, work schedules that include the time period between midnight and early morning are expected to have a higher impact than working hours outside of this period. Many of the studies stated that shift work most often included work at night. Some studies also categorized workers with poorly defined working hours, or work in the afternoon or evening, as shift workers despite the fact that not all of these were necessarily exposed to work at night. Such misclassification would likely not be differential and thus an inaccurate exposure assessment could underestimate the risk. Bøggild et al (20) and Yadegarfar et al (25) classified irregular and afternoon or evening (non-night shift workers) as shift work, they reported no increase of relative risks. They did not supply any information on the distribution of evening and night shift workers and, thus, the possibility for misclassification cannot be ruled out. 
Four studies included separate analyses on the type of shift work $(21,23,28,33)$, with and without night work, where no clear indications were found for stronger effects among shift workers mainly working during nights compared to those who did not work at night. Five studies obtained information on working hours from fairly complete company records $(24,25,28,29$, $35)$, three studies used aggregated measures $(26,31,33)$, while six used self-reporting (20-23, 27, 30). Independent exposure information at the individual level, as obtained from company records, should provide higher quality exposure data. In the aforementioned five studies which should present better quality exposure information, relative risk estimates ranged from 0.64 to 1.11 , showing no tendency of increased risk. However, these studies were also mortality studies, where the accuracy of diagnosis may be quite low. With the exception of Bøggild et al (20), all the studies based on self-reported working hours showed increased risk estimates. Two of these $(22,23)$ used retrospective exposure assessment, making them vulnerable to recall bias.

\section{Confounding and effect mediators}

Important risk factors for ischemic heart disease include blood pressure, blood lipids, body mass index, smoking, and socioeconomic status. The effect of shift work may be mediated through unfavorable changes in behavioral factors if these are related to the shift work. This mechanism should be considered when controlling potential confounders in studies on shift workers' risk of ischemic heart disease. Controlling pre-employment smoking, blood pressure and blood lipids would be adequate and this was done in two of the studies $(24,25)$. Smoking was reported in six studies $(20,22,23,25,27,30)$, and was generally more frequent among shift workers. A modest attenuation in risk estimates was seen after a multivariate adjustment, although residual confounding due to an imprecise assessment of smoking and possibly other lifestyle factors would still be possible (44). Five studies provided information on crude (or only age-adjusted) and fully adjusted risk estimates. The adjusted risk estimates were all close to unity and only minor changes in risk estimates in the expected direction appeared after adjustment, two showing increases $(24,30)$, and three showing decreases $(20,25,27)$.

Some papers have reported that starting shift work is related to gains in body weight (45-48), increased smoking, and unfavorable changes in blood lipids (19, 49-52). These studies provide some evidence for an effect of shift work mediated through these factors; thus controlling such factors in the analyses would tend to attenuate the effect of shift work. On the other hand, a recent study among newly educated Danish social and healthcare workers showed quite a strong relation between smoking and later engagement in shift work (53). Looking at the five studies that provided adjusted as well as unadjusted risk estimates, there is no indication that confounder control had a major impact on the crude risk estimates $(20,24,25,27,30)$. Modest changes were seen, indicating that high quality information on potential confounders and mediators are important to clarify any true effects of shift work from residual confounding, especially when estimates of relative risk, as in most of the included studies, are around or slightly above unity. As mentioned, a minority of the studies reported adjusted and unadjusted estimates to guide interpretation of the results. However, untangling effect mediation from true confounding would require studies that included pre-employment and repeated assessments of potential confounding/mediating factors.

Bøggild et al (20) and Yadegarfar et al (25) found that socioeconomic factors confounded risk estimates even though both studies used industrial cohorts, where socioeconomic factors are expected to be more comparable than in studies using general population samples. Most other studies that used industrial cohorts, where social background could be considered quite homogeneous, did not perform further controls of socioeconomic factors, leaving the possibility of residual confounding $(22,27,30,35)$.

\section{Exposure response}

The impact of cumulative exposure to shift work has not been clearly stated in the theories about shift work and ischemic heart disease. It is also often unclear whether the effects of shift work are expected to cease or continue after exposure has ended. Virkkunen et al (54) performed further analyses on subgroups of shift workers using a longer follow-up; the results indicated a decreasing risk over time. However, most studies considered workers "exposed" if they had ever done shift work even for a minimum period. Follow-up commonly ended when participants reached a certain age, usually the mid-seventies. On the basis of this, it seems that most authors anticipate some gradual development of the disease, and that the risk will increase according to cumulative exposure.

Five studies $(22,24,25,27,35)$ analyzed risk in relation to years undertaking shift work. Two studies found an increase in risk according to the number of years in shift work - one after more than 30 years (35) and the other after more than ten years, but with a decrease after more than 20 years (22). Both studies had important limitations. Two studies of good quality found no relationship between risk and years in shift work $(24,25)$. One study (27) among females showed an increased risk after six years, but the number of cases examined was small. 


\section{Other relevant data}

Bøggild et al (20) and Knutsson et al (23) considered the evidence for an unfavorable relation of shift work to cardiovascular risk factors, such as cholesterol and blood pressure, and found mixed results. Although no firm conclusion could be drawn, some studies indicated that cholesterol and triglycerides seemed to be raised as a result of shift work (12). Shift work may also be associated with hypertension, although this was not supported by a recent study (54). Based on cross-sectional data, Karlsson et al $(18,19)$ suggested that metabolic disturbances (eg, obesity, unfavorable levels of blood lipids) may be related to shift work. Two recent longitudinal studies found that shift work was related to weight gain $(46,48)$. One study found an increased risk of smoking and a decreased risk of not quitting among shift workers (52). Thus, some evidence exists that metabolic disturbances and changes in smoking habits are related to starting shift work and supports the hypothesis that the risk of ischemic heart disease could be mediated through such changes.

\section{Concluding remarks}

We found 14 studies reporting on the risk of ischemic heart disease in relation to shift work. Seven reported mortality data, six were based on incidence data and one used both types. The range of relative risk estimates derived from these studies was $0.6-2.3$. Two mortality data studies, both with few cases, reported an increase in risk. The interpretation of these studies was limited by the low number of cases used and the unknown validity of exposure information. Six mortality studies reported relative risks around unity. Of these, two used exposure information of high quality and thorough confounder control. However, inaccurate outcome assessment in mortality studies may tend to underestimate a true effect of shift work. Seven studies used incidence data combining non-fatal and fatal cases. Of these, all but one study reported relative risk slightly above unity. These associations were statistically significant in two studies. Interpretation of these results is limited by methodological problems such as inadequate confounder control, differential exposure misclassification, and an inability to rule out selection bias.

The available evidence concerning the influence of the type and duration of shift work, as well as gender, on the risk of ischemic heart disease is too limited to permit any conclusions on these issues. Other relevant data on cardiovascular risk factors provide some supportive evidence for an effect of shift work mediated by unfavorable changes in metabolic mechanisms and smoking habits. Given the criteria of the Scientific Committee of the Danish Society of Occupational
Health for limited evidence (ie, "a casual relationship is possible [. . .] but it is not unlikely that this relationship can be explained by chance, bias or confounding"), this review finds limited evidence of a causal association between shift work and ischemic heart disease.

\section{Acknowledgements}

The authors are grateful to the following individuals for their reviews and valuable comments on this manuscript: Anders Ahlbom, Professor and Head of Division of Epidemiology at the Institute of Environmental Medicine of the Karolinska Institute in Stockholm, Sweden; Henrik Bøggild, PhD and Head of Department of Public Health Medical Officers of Northern Jutland at the Danish National Board of Health; and George Davey-Smith, Professor of Clinical Epidemiology at the University of Bristol in the UK. The study was funded by a grant from the Danish Working Environment Research Fund.

\section{References}

1. Selwyn A, Braunwald E. Ischemic heart disease. In: Braunwald E, Isselbacher K, Petersdorf R, Wilson J, Martin J, Fauci A, editors. Harrison's principles of internal medicine. 11 ed. New York (NY): McGraw-Hill Book Company; 1987. p 975-982.

2. Allender S, Scarborough P, Peto V, Rayner M, Leal J, Luengo-Fernandez R, et al. European cardiovascular disease statistics 2008. European Heart Network, Brussels, Belgium; 2008.

3. Madsen M, Gudnason V, Pajak A, Palmieri L, Rocha EC, Salomaa V, et al. Population-based register of acute myocardial infarction: manual of operations. Eur J Cardiovasc Prev Rehabil. 2007;14 suppl 3:S3-22.

4. Danish Heart foundation and National Institute of Public Health. Heart statistics 2004. Copenhagen: Danish Heart foundation and National Institute of Public Health; 2004.

5. Galobardes B, Smith GD, Lynch JW. Systematic review of the influence of childhood socioeconomic circumstances on risk for cardiovascular disease in adulthood. Ann Epidemiol. 2006;16(2):91-104.

6. Gonzalez MA, Rodriguez AF, Calero JR. Relationship between socioeconomic status and ischaemic heart disease in cohort and case-control studies: 1960-1993. Int J Epidemiol. 1998;27(3):350-8.

7. Bogers RP, Bemelmans WJ, Hoogenveen RT, Boshuizen HC, Woodward M, Knekt P, et al. Association of overweight with increased risk of coronary heart disease partly independent of blood pressure and cholesterol levels: a meta-analysis of 
21 cohort studies including more than 300000 persons. Arch Intern Med. 2007;167(16):1720-8.

8. Graham I, Atar D, Borch-Johnsen K, Boysen G, Burell G, Cifkova R, et al. European guidelines on cardiovascular disease prevention in clinical practice: executive summary. Eur Heart J. 2007;28(19):2375-414.

9. Hardoon SL, Whincup PH, Lennon LT, Wannamethee SG, Capewell S, Morris RW. How much of the recent decline in the incidence of myocardial infarction in British men can be explained by changes in cardiovascular risk factors? Evidence from a prospective population-based study. Circulation. 2008;117(5):598-604.

10. Unal B, Critchley JA, Capewell S. Explaining the decline in coronary heart disease mortality in England and Wales between 1981 and 2000. Circulation. 2004;109(9):1101-7.

11. Unal B, Critchley JA, Capewell S. Modelling the decline in coronary heart disease deaths in England and Wales, 19812000: comparing contributions from primary prevention and secondary prevention. BMJ. 2005;331(7517):614.

12. Bøggild H, Knutsson A. Shift work, risk factors and cardiovascular disease [review]. Scand J Work Environ Health. 1999;25(2):85-99.

13. Knutsson A, Bøggild H. Shiftwork and cardiovascular disease: review of disease mechanisms. Rev Environ Health. 2000;15(4):359-72.

14. Kristensen TS. Cardiovascular diseases and the work environment. A critical review of the epidemiologic literature on nonchemical factors [review]. Scand J Work Environ Health. 1989;15(3):165-79.

15. Moore-Ede MC, Richardson GS. Medical implications of shift-work. Annu Rev Med. 1985;36:607-17.

16. European Foundation for the Improvement of living And Working Conditions. Third European survey on working conditions 2000. Luxembourg: Office for Official Publications of the European Communities; 2001.

17. European Foundation for the Improvement of living And Working Conditions. Fourth European Working Condition Survey. Luxembourg: Office for Official Publications of the European Communities; 2007.

18. Karlsson B, Knutsson A, Lindahl B. Is there an association between shift work and having a metabolic syndrome? Results from a population based study of 27,485 people. Occup Environ Med. 2001;58(11):747-52.

19. Karlsson BH, Knutsson AK, Lindahl BO, Alfredsson LS. Metabolic disturbances in male workers with rotating threeshift work. Results of the WOLF study. Int Arch Occup Environ Health. 2003;76(6):424-30.

20. Bøggild H, Suadicani P, Hein HO, Gyntelberg F. Shift work, social class, and ischaemic heart disease in middle aged and elderly men; a 22 year follow-up in the Copenhagen Male Study. Occup Environ Med. 1999;56(9):640-5.

21. Fujino Y, Iso H, Tamakoshi A, Inaba Y, Koizumi A, Kubo $\mathrm{T}$, et al. A prospective cohort study of shift work and risk of ischemic heart disease in Japanese male workers. Am J Epidemiol. 2006;164(2):128-35.
22. Knutsson A, Akerstedt T, Jonsson BG, Orth-Gomer K. Increased risk of ischaemic heart disease in shift workers. Lancet. 1986;2(8498):89-92.

23. Knutsson A, Hallquist J, Reuterwall C, Theorell T, Akerstedt T. Shiftwork and myocardial infarction: a case-control study. Occup Environ Med. 1999;56(1):46-50.

24. McNamee R, Binks K, Jones S, Faulkner D, Slovak A, Cherry NM. Shiftwork and mortality from ischaemic heart disease. Occup Environ Med. 1996;53(6):367-73.

25. Yadegarfar G, McNamee R. Shift work, confounding and death from ischaemic heart disease. Occup Environ Med. 2008;65(3):158-63.

26. Alfredsson L, Karasek R, Theorell T. Myocardial infarction risk and psychosocial work environment: an analysis of the male Swedish working force. Soc Sci Med. 1982;16(4):463-7.

27. Kawachi I, Colditz GA, Stampfer MJ, Willett WC, Manson JE, Speizer FE, et al. Prospective study of shift work and risk of coronary heart disease in women. Circulation. 1995;92(11):3178-82.

28. Steenland K, Fine L. Shift work, shift change, and risk of death from heart disease at work. Am J Ind Med. 1996;29(3):278-81.

29. Taylor PJ, Pocock SJ. Mortality of shift and day workers 1956-68. Br J Ind Med. 1972;29(2):201-7.

30. Tenkanen L, Sjöblom T, Kalimo R, Alikoski T, Härmä M. Shift work, occupation and coronary heart disease over 6 years of follow-up in the Helsinki Heart Study. Scand J Work Environ Health. 1997;23(4):257-65.

31. Tuchsen F. Working hours and ischaemic heart disease in Danish men: a 4-year cohort study of hospitalization. Int J Epidemiol. 1993;22(2):215-21.

32. Tüchsen F, Hannerz H, Burr H. A 12 year prospective study of circulatory disease among Danish shift workers. Occup Environ Med. 2006;63(7):451-5.

33. Virtanen SV, Notkola V. Socioeconomic inequalities in cardiovascular mortality and the role of work: a register study of Finnish men. Int J Epidemiol. 2002;31(3):614-21.

34. Angersbach D, Knauth P, Loskant H, Karvonen MJ, Undeutsch K, Rutenfranz J. A retrospective cohort study comparing complaints and diseases in day and shift workers. Int Arch Occup Environ Health. 1980;45(2):127-40.

35. Karlsson B, Alfredsson L, Knutsson A, Andersson E, Torén K. Total mortality and cause-specific mortality of Swedish shift- and dayworkers in the pulp and paper industry in 1952-2001. Scand J Work Environ Health. 2005;31(1):30-5.

36. Bonde JP, Andersen JH, Frost P, Kaergaard A, Kolstad HA, Thulstrup AM. Helbredsundersøgelser ved natarbejde [Health examinations in connection with night work]. Ugeskr Laeger. 2007;169(21):2005-7.

37. Tüchsen F, Andersen O, Olsen J. Referral bias among health workers in studies using hospitalization as a proxy measure of the underlying incidence rate. J Clin Epidemiol. 1996;49(7):791-4.

38. Kivimäki M, Virtanen $M$, Elovainio $M$, Väänänen A, Keltikangas-Järvinen L, Vahtera J. Prevalent cardiovascular disease, 
risk factors and selection out of shift work. Scand J Work Environ Health 2006;32(3):204-8.

39. Macleod J, Davey SG, Heslop P, Metcalfe C, Carroll D, Hart C. Psychological stress and cardiovascular disease: empirical demonstration of bias in a prospective observational study of Scottish men. BMJ. 2002;324(7348):1247-51.

40. Macleod J, Smith GD. Re: "does job strain increase the risk for coronary heart disease or death in men and women? The Framingham offspring study". Am J Epidemiol. 2004; 60(10):1031-2.

41. Nielsen NR, Kristensen TS, Prescott E, Larsen KS, Schnohr P, Gronbaek M. Perceived stress and risk of ischemic heart disease: causation or bias? Epidemiology. 2006;17(4):391-7.

42. Coady SA, Sorlie PD, Cooper LS, Folsom AR, Rosamond WD, Conwill DE. Validation of death certificate diagnosis for coronary heart disease: the Atherosclerosis Risk in Communities (ARIC) Study. J Clin Epidemiol. 2001;54(1):40-50.

43. Macleod J, Davey SG, Heslop P, Metcalfe C, Carroll D, Hart C. Psychological stress and cardiovascular disease: empirical demonstration of bias in a prospective observational study of Scottish men. BMJ. 2002;324(7348):1247-51.

44. Davey Smith G, Ebrahim S. Mendelian randomization: genetic variants as instruments for strengthening causal inference in observational studies. In: Weinstein M, Vaupel J, Watcher K, editors. Biosocial surveys. Washington (DC): The National Academies Press; 2008. p 336-66.

45. Atkinson G, Fullick S, Grindey C, Maclaren D. Exercise, energy balance and the shift worker. Sports Med. 2008;38(8):671-85.

46. Biggi N, Consonni D, Galluzzo V, Sogliani M, Costa G. Metabolic syndrome in permanent night workers. Chronobiol Int. 2008;25(2):443-54.
47. Di Lorenzo L, De Pergola G, Zocchetti C, L'Abbate N, Basso A, Pannacciulli N, et al. Effect of shift work on body mass index: results of a study performed in 319 glucose-tolerant men working in a Southern Italian industry. Int J Obes Relat Metab Disord. 2003;27(11):1353-8.

48. Suwazono Y, Dochi M, Sakata K, Okubo Y, Oishi M, Tanaka $\mathrm{K}$, et al. A longitudinal study on the effect of shift work on weight gain in male Japanese workers. Obesity (Silver Spring). 2008;16(8):1887-93.

49. Karlsson B, Knutsson A, Lindahl B. Is there an association between shift work and having a metabolic syndrome? Results from a population based study of 27,485 people. Occup Environ Med. 2001;58(11):747-52.

50. van Amelsvoort LG, Schouten EG, Kok FJ. Duration of shiftwork related to body mass index and waist to hip ratio. Int J Obes Relat Metab Disord. 1999;23(9):973-8.

51. van Amelsvoort LG, Schouten EG, Kok FJ. Impact of one year of shift work on cardiovascular disease risk factors. J Occup Environ Med. 2004;46(7):699-706.

52. van Amelsvoort LG, Jansen NW, Kant I. Smoking among shift workers: more than a confounding factor. Chronobiol Int. 2006;23(6):1105-13.

53. Nabe-Nielsen K, Garde AH, Tüchsen F, Hogh A, Diderichsen F. Cardiovascular risk factors and primary selection into shift work. Scand J Work Environ Health. 2008;34(3):206-12.

54. Virkkunen H, Härmä M, Kauppinen T, Tenkanen L. Shift work, occupational noise and physical workload with ensuing development of blood pressure and their joint effect on the risk of coronary heart disease. Scand J Work Environ Health. 2007;33(6):425-34.

Received for publication: 25 February 2009 